\title{
Caracterização Genética de ACessos de Egéria (Egeria spp.) Coletados no Estado de São Paulo Utilizando RAPD ${ }^{1}$
}

\author{
Genetic Characterization of Egeria (Egeria spp.) Accesses Collected in São Paulo, Using RAPD
}

\author{
MARTINS, D. ${ }^{2}$, CARDOSO, L.R. ${ }^{3}$, MORI, E.S. ${ }^{2}$ e TANAKA R.H. ${ }^{4}$
}

\begin{abstract}
RESUMO - Este trabalho constituiu-se na análise da variabilidade genética de acessos de egéria (Egeria spp.) coletados em sete reservatórios de geração de energia do Estado de São Paulo. Foi utilizada a técnica de RAPD (DNA polimórfico amplificado ao acaso), na qual seis primers (X03, Y09, Y11, Z11, Z12 e W06) permitiram a análise de 23 locos polimórficos na espécie Egeria densa. Os materiais dos reservatórios de Nova Avanhandava e Promissão foram os mais semelhantes geneticamente, visto que se localizam em seqüência no rio Tietê. Os reservatórios de Salto Grande e Promissão apresentaram plantas com o maior índice de distância genética $(0,1792)$. Para a espécie Egeria najas foram analisados 52 locos polimórficos, resultantes da amplificação de nove primers (X01, X02, X03, X05, X09, X10, X11, Z11 e Z13). A maior distância genética verificada foi de 0,2791, entre os reservatórios de Ibitinga e Jupiá, como conseqüência da distância geográfica entre esses reservatórios.
\end{abstract}

Palavras-chave: planta aquática, DNA, dispersão, Egeria densa, Egeria najas.

\begin{abstract}
The aim of this research was to study the genetic variability of egeria (Egeria spp.) accesses, sampled in seven reservoirs throughout the state of São Paulo. The RAPD (Random Amplified Polymorphic DNA) analysis was used, with six primers (X03, Y09, Y11, Z11, Z12 and W06) furnishing 23 polymorphic loci for Egeria densa. The plants from the Avanhandava and Promissão reservoirs showed the greatest genetic similarity, since both are located on the Tietê river. The Salto Grande and Promissão reservoirs presented plants with the greatest genetic distance (0.1792). For the Egeria najas species, 52 polymorphic loci were analyzed and nine primers (X01, X02, X03, X05, X09, X1O, X11, Z11 and Z13) were selected. The greatest genetic distance verified was 0.2791 , between the Ibitinga and Jupiá reservoir samples, caused by the long geographic distance between them.
\end{abstract}

Key words: aquatic plant, DNA, Egeria densa, Egeria najas, dispersion.

\section{INTRODUÇÃO}

Os benefícios promovidos por populações de macrófitas aquáticas geralmente tornamse problemas indesejáveis quando ocorre uma "explosão" no desenvolvimento dessas plantas (Thomaz, 1998). O Brasil possui várias espécies de plantas aquáticas nativas vivendo em situação de equilíbrio com o meio. Para que essa condição seja alterada, é necessário que o ambiente tenha suas características modificadas, na maioria das vezes por influência antrópica. Os exemplos mais flagrantes localizam-se nas proximidades de centros urbanos como São Paulo, Belo Horizonte, Rio de Janeiro e Recife, em lagos e reservatórios eutrofizados pela introdução de dejetos urbanos (Pitelli, 1998).

Dentre as macrófitas aquáticas submersas existentes no Brasil, a planta daninha de maior expressão em reservatórios de geração de energia e represas rurais é a egéria (Egeria densa).

Recebido para publicação em 10.12.2002 e na forma revisada em 15.4.2003.

2 Professor Dr., Departamento de Produção Vegetal da Faculdade de Ciências Agronômicas - FCA/UNESP, Cx. Postal 237, 18603-970 Botucatu-SP; ${ }^{3}$ Eng.-Agr., M.S., FCA/UNESP. ${ }^{4}$ Eng.-Agr., M.S., Departamento de Meio Ambiente, CESP. 
Entretanto, é crescente o número de reservatórios populados com Egeria najas. Essas plantas desenvolvem-se bem em corpos hídricos com águas transparentes e sedimentos ricos, amplas faixas de $\mathrm{pH}$ e temperaturas amenas.

Os prejuízos causados pelo crescimento maciço de plantas de egéria incluem favorecimento para procriação de vetores de doenças, impedimento à navegação e pesca e interferência em atividades de lazer das comunidades que vivem próximas a esses recursos hídricos, além dos danos causados ao processo de geração de energia das hidrelétricas.

A comercialização de egéria como planta ornamental para aquários viabilizou sua disseminação por várias partes do mundo. É encontrada no Japão e, nos Estados Unidos, distribui-se pela Califórnia, Arizona, Washington e Flórida.

A relevância dos prejuízos econômicos causados pelas plantas daninhas aquáticas submersas nos países desenvolvidos incentivou a realização de pesquisas na área de biologia molecular. Estudos realizados com egéria sugerem a realização de caracterizações genéticas com acessos coletados no Brasil, para uma possível verificação da origem das plantas introduzidas nos Estados Unidos, bem como o auxílio no manejo químico, com enfoque em seleção e resistência a herbicidas.

Dessa forma, o presente trabalho analisou a distância genética existente em acessos de egéria coletados em sete reservatórios do Estado de São Paulo.

\section{MATERIAL E MÉTODOS}

\section{Coleta de Egeria spp.}

Foram realizadas incursões em 18 reservatórios de usinas hidrelétricas do Estado de São Paulo, porém foram encontradas plantas de Egeria densa apenas nos reservatórios de Salto Grande (SAG), Nova Avanhandava (NAV) e Promissão (PRO) e de Egeria najas nos reservatórios de Ilha Solteira (ILS), Ibitinga (IBI) e Três Irmãos (TRI). No reservatório de Jupiá (JUP) foram encontradas as duas espécies. As amostragens das plantas foram realizadas nas duas margens dos rios. O material coletado foi trazido em sacos plásticos para a área experimental do Núcleo de Pesquisas Avançadas em Matologia, ligado ao Departamento de Produção Vegetal da UNESPFCA, campus de Botucatu/SP. O cultivo dessas plantas foi feito em vasos plásticos com solo de várzea, acondicionados em caixas d'água.

\section{Análise da variabilidade genética}

Parte do material vegetal das plantas de egéria, depois de bem lavadas, para eliminar a presença de algas, foi submetida à extração do DNA nuclear segundo o protocolo de Lodhi et al. (1994), com pequenas modificações, a fim de garantir a qualidade do DNA. Utilizou-se a técnica de RAPD com base no protocolo de Williams et al. (1990). Para a escolha dos primers, foi adotado um procedimento utilizado no Departamento de Horticultura da Universidade de Wisconsin, em Madison, EUA. Foram testados, no total, 156 primers de 10 bases de seqüência arbitrária. Os primers utilizados foram da Operon Technologies Inc., pertencentes aos kits OPA, OPP, OPF e OPC, bem como quatro kits sintetizados pela Life Technologies do Brasil, para possibilitar a escolha dos polimórficos e eficientes para as populações de egéria.

Inicialmente, dos primers testados, nove foram escolhidos para conduzir as reações de RAPD com o DNA extraído das plantas de Egeria densa. Entretanto, do total, dois não apresentaram boa amplificação das amostras e um revelou padrão monomórfico. Assim, seis foram considerados nas análises. Para Egeria najas, nove primers foram eficientes e polimórficos. Os primers usados nas reações de RAPD constituem-se de 10 nucleotídeos de seqüência arbitrária, listados na Tabela 1.

Foram feitas reações de RAPD de $20 \mu \mathrm{L}$, modificadas do protocolo original de Williams et al. (1990). Ao saírem do termociclador, as amostras foram corridas em gel de agarose $1,5 \%$ a $110 \mathrm{~V}$, por três horas. Utilizaram-se $12 \mu \mathrm{L}$ de Ladder $100 \mathrm{pb}$ como marcador e $4 \mu \mathrm{L}$ de TC como corante, para permitir visualização no "Eagle Eye II". As análises foram feitas no programa computacional POPGENE 32.

As distâncias genéticas entre as plantas dos diferentes biótipos foram determinadas pelo coeficiente Simple Matching (SM); o 
método UPGMA (Unweighted Pair-Group Method with Arithmetic Averaging) foi utilizado para agrupar as plantas de uma mesma localidade, com base nas suas similaridades qualitativas (coeficiente SM). Os resultados obtidos foram apresentados por meio de dendrograma.

Tabela 1 - Primers utilizados nos estudos com Egeria densa e Egeria najas

\begin{tabular}{|c|c|c|c|}
\hline \multicolumn{2}{|c|}{ Primers } & \multirow{2}{*}{ E. densa } & \multirow{2}{*}{ E. najas } \\
\cline { 1 - 2 } Identificação & Seqüência & & \\
\cline { 1 - 2 } X 01 & CTG GGC ACG A & - & $\mathrm{X}$ \\
X 02 & TTC CGC CAC C & - & $\mathrm{X}$ \\
X 03 & TGG CGC AGT G & X & X \\
X 05 & CCT TTC CCT C & - & X \\
X 09 & GGT CTG GTT G & - & X \\
X 10 & CCC TAG ACT G & - & X \\
X 11 & GGA GCC TCA G & - & X \\
Y 09 & AGC AGC GCA C & X & - \\
Y 11 & AGA CGA TGG G & X & - \\
Z 11 & CTC AGT CGC A & X & X \\
Z 12 & TCA ACG GGA C & X & - \\
Z 13 & GAC TAA GCC C & - & X \\
W 06 & AGG CCC GAT G & X & - \\
\hline
\end{tabular}

\section{RESULTADOS E DISCUSSÃO}

\section{Egeria densa}

Os padrões de bandas gerados pelas reações de RAPD foram nítidos e produziram bandas de média a boa intensidade. Os seis primers utilizados permitiram boa amplificação de todas as amostras e demonstraram a existência de variabilidade genética entre as populações, produzindo bandas polimórficas.

Na Tabela 2 estão apresentados os números de locos observados para cada um dos seis primers, num total de 23 e média de 3,8 locos por primer analisado.

Na Tabela 3 estão apresentados a porcentagem e o número de locos polimórficos para as quatro populações estudadas. O reservatório de Jupiá revelou um material genético um pouco abaixo da média $(72,83 \%)$ de locos polimórficos, ao contrário dos demais reservatórios, caracterizando-se, dessa maneira, por possuir acessos de egéria menos variáveis geneticamente.
Tabela 2 - Número de locos encontrados para cada primer estudado, em Egeria densa

\begin{tabular}{|c|c|}
\hline Primer & № de locos/primer \\
\hline X 03 & 3 \\
Y 09 & 10 \\
Y 11 & 3 \\
Z 11 & 1 \\
Z 12 & 4 \\
W 06 & 2 \\
\hline Total & 23 \\
\hline Média & 3,8 \\
\hline
\end{tabular}

Tabela 3 - Local, porcentagem e número de locos polimórficos para as quatro populações de Egeria densa estudadas

\begin{tabular}{|l|c|c|}
\hline \multicolumn{1}{|c|}{ Local de coleta } & $\begin{array}{c}\% \text { de locos } \\
\text { polimórficos }\end{array}$ & $\begin{array}{c}\mathrm{N}^{\mathrm{o}} \text { de locos } \\
\text { polimórficos }\end{array}$ \\
\hline Nova Avanhandava & 73,91 & 17 \\
Promissão & 73,91 & 17 \\
Salto Grande & 73,91 & 17 \\
Jupiá & 69,57 & 16 \\
\hline Média & 72,83 & 16,75 \\
\hline
\end{tabular}

Na Tabela 4 estão apresentados os dados acima da diagonal, referentes à identidade genética calculada com base em Nei (1972). Os valores variam de 0,8455 a 0,9021 entre as populações de Salto Grande e Jupiá e Nova Avanhandava e Jupiá, respectivamente. Os valores abaixo da diagonal referem-se aos dados de distância genética, sendo maiores entre as populações de Salto Grande e Jupiá, conseqüentemente.

Segundo Kadono et al. (1997), que estudaram a variabilidade genética pelo método isoenzimático, em acessos de Egeria densa e Elodea nuttalli coletados em vários locais do Japão não foram detectadas variações genéticas, sugerindo que os acessos de egéria eram provenientes de um mesmo clone introduzido no Japão.

Weiss (1997), além de concluir que Egeria densa era diferente geneticamente de Elodea, verificou pequenas diferenças genéticas entre acessos de Egeria densa coletados na Califórnia. 
Tabela 4 - Dados de identidade e distância genética para Egeria densa

\begin{tabular}{|l|c|c|c|c|}
\hline \multicolumn{1}{|c|}{ População } & Salto Grande & Nova Avanhandava & Promissão & Jupiá \\
\hline Salto Grande & $* * * * *$ & 0,8852 & 0,8510 & 0,8455 \\
Nova Avanhandava & 0,1219 & $* * * * *$ & 0,8921 & 0,9021 \\
Promissão & 0.1614 & 0,1142 & $* * * * *$ & 0,8478 \\
Jupiá & 0,1678 & 0,1030 & 0,1651 & $* * * * *$ \\
\hline
\end{tabular}

A Figura 1 apresenta o dendrograma gerado a partir da análise dos dados de RAPD. Podese observar que a população de Salto Grande foi a mais diferente geneticamente, concordando com o fato de o reservatório ser o mais distante geograficamente. O material genético de Nova Avanhandava foi mais próximo do material de Jupiá. A semelhança genética entre as plantas desses dois reservatórios indica uma possível colonização de Jupiá com plantas de Nova Avanhandava, devido ao caminhamento de plantas pelo rio Tietê.

Apesar de os reservatórios de Promissão e Nova Avanhandava estarem em seqüência no rio Tietê, houve maior distância genética quando se considerou o de Jupiá. No entanto, deve-se ressaltar que a máxima distância genética entre os reservatórios $(0,1678)$ não é muito elevada, considerando que a egéria é uma planta nativa da bacia do Paraná, a qual, provavelmente, contém plantas masculinas e femininas. Portanto, ocasionalmente, pode se reproduzir via sementes.

\section{Egeria najas}

Os padrões gerados pelas reações de RAPD em Egeria najas foram nítidos, com produção de bandas de boa a ótima intensidade. Os nove primers utilizados, de modo geral, realizaram boa amplificação, porém as amostras ILS $11 \mathrm{e}$ IBI 05 falharam em todos eles. Alguma mudança de $\mathrm{pH}$ pode ter ocorrido no DNA dessas amostras, interferindo na sua amplificação.

Na Tabela 5 estão apresentados os números de locos observados para cada um dos nove primers, num total de 52 e média de 5,77 locos por primer analisado.

Tabela 5 - Número de locos encontrados para cada primer estudado, em Egeria najas

\begin{tabular}{|c|c|}
\hline Primer & No $^{\text {o de locos/primer }}$ \\
\hline X 01 & 7 \\
X 02 & 3 \\
X 03 & 6 \\
X 05 & 6 \\
X 09 & 4 \\
X 10 & 2 \\
X 11 & 10 \\
Z 11 & 7 \\
Z 13 & 7 \\
\hline Total & 52 \\
\hline Média & 5,77 \\
\hline
\end{tabular}
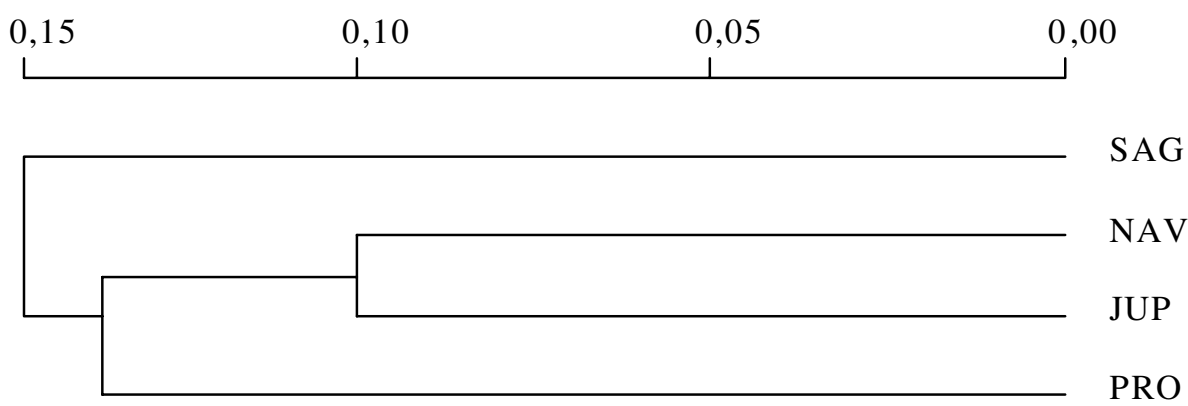

Figura 1 - Dendrograma de distância genética entre as populações de Egeria densa (SAG - Salto Grande; NAV- Nova Avanhandava; JUP - Jupiá; PRO- Promissão). 
Tabela 6 - Local, porcentagem e número de locos polimórficos para as quatro populações de Egeria najas estudadas

\begin{tabular}{|l|c|c|}
\hline Local de coleta & $\begin{array}{c}\text { \% de locos } \\
\text { polimórficos }\end{array}$ & $\begin{array}{c}\mathrm{n}^{\mathrm{o}} \text { de locos } \\
\text { polimórficos }\end{array}$ \\
\hline Ilha Solteira & 63,46 & 33 \\
Ibitinga & 82,69 & 43 \\
Três Irmãos & 40,38 & 21 \\
Jupiá & 32,69 & 17 \\
\hline Média & 54,80 & 28,5 \\
\hline
\end{tabular}

Encontram-se na Tabela 6 a porcentagem e o número de locos polimórficos para as quatro populações estudadas. O reservatório Três Irmãos apresentou-se mais polimórfico que os demais, com porcentagem de locos polimórficos bem acima da média.

Considerando que a porcentagem de locos polimórficos observada para a população de Egeria najas no reservatório de Jupiá foi maior do que a observada em Egeria densa, pode-se dizer que esta espécie foi mais variável geneticamente que a primeira.

Na Tabela 7 estão apresentados os dados de identidade e distância genética. A maior similaridade genética foi encontrada entre os acessos dos reservatórios de Ilha Solteira e Três Irmãos $(0,9402)$. Apesar da distância geográfica entre os reservatórios, Ibitinga apresentou índice de similaridade igual a 0,9267 em relação a Ilha Solteira. No entanto, a distância genética foi maior quando comparada aos reservatórios de Três Irmãos e Jupiá.

Mori et al., estudando a variabilidade isoenzimática e de DNA de Egeria najas, verificaram haver diferenças genéticas entre os acessos coletados nos reservatórios de Jupiá, no rio Tietê, no canal de Pereira Barretos e no rio São José dos Dourados. Os índices de diversidade genética observados nesse estudo estão dentro do intervalo encontrado para Egeria najas pelos autores.

Pode-se observar, pela Figura 2, a representação visual das distâncias genéticas entre os reservatórios.

As similaridades genéticas entre Ilha Solteira e Três Irmãos foram superiores a 0,90, indicando provável colonização ocorrida pelo canal de Pereira Barreto. No entanto, a semelhança entre os materiais de Ilha Solteira e Ibitinga sugere uma possivel ação antrópica, que poderia ser confirmada com o estudo de outros reservatórios localizados entre eles.

Tabela 7 - Dados de identidade e distância genética para Egeria najas

\begin{tabular}{|l|c|c|c|c|}
\hline \multicolumn{1}{|c|}{ População } & Ilha Solteira & Ibitinga & Três Irmãos & Jupiá \\
\hline Ilha Solteira & $* * * * *$ & 0,9267 & 0,9402 & 0,8281 \\
Ibitinga & 0,0761 & $* * * * *$ & 0,8701 & 0,7565 \\
Três Irmãos & 0,0616 & 0,1391 & $* * * * *$ & 0,8314 \\
Jupiá & 0,1887 & 0,2791 & 0,1847 & $* * * * *$ \\
\hline
\end{tabular}

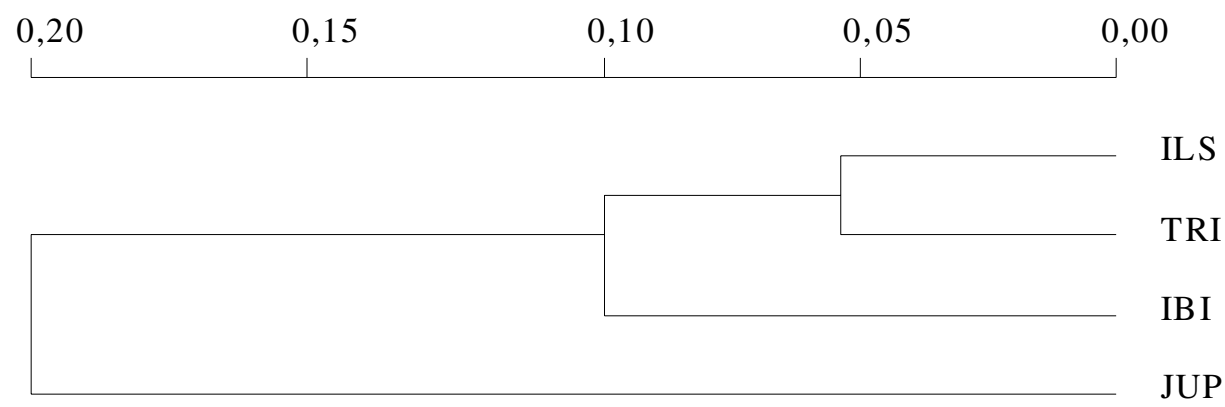

Figura 2 - Dendrograma de distância genética entre as populações de Egeria najas (ILS - Ilha Solteira; TRI - Três Irmãos; IBI - Ibitinga; JUP - Jupiá). 


\section{LITERATURA CITADA}

AUNG, S.; NIJAGAL, A. Differences between biotypes of Egeria densa are detected with Random Amplified Polymorphic (RAPD) analysis. Aquatic Weed Control Investigations. Annual Report, 1995. p. 12-4.

BAINS, W. Biotechnology from A to Z. 4. ed. Oxford: University Press, 1995. 357 p.

FERREIRA, M. E.; GRATTAPAGLIA, D. Polimorfismo de DNA amplificado ao acaso (RAPD). In: Introdução ao uso de marcadores RAPD e RFLP em análise genética. Brasília: EMBRAPA-CERNAGEM, 1995. p. 38-53.

HOLM, L.; YEO, R. The biology, control and utilization of aquatic weeds. Part I. Weeds Today, p. 7-13, 1980.

HOLM, L. G.; WELDON, L. W.; BLACKBURN, R. D. Aquatic weeds. Science, v. 166, p. 699-709, 1969.

KISSMANN, K. G. Plantas infestantes e nocivas. 2. ed. São Bernardo do Campo: BASF 1997. 825 p.
NEI, M. Genetic distance beetween populations. Am. Naturalist, v. 106, p. 283-292, 1972.

PITELLI, R. A. Macrófitas aquáticas do Brasil. In: WORKSHOP DE CONTROLE DE PLANTAS AQUÁTICAS, 1998, Brasília. Anais... Brasília: 1998. p. 12-15.

THOMAZ, S. M. Explosões populacionais de plantas aquáticas: sintoma de um problema. In: WORKSHOP DE CONTROLE DE PLANTAS AQUÁTICAS, 1998, Brasília. Anais... Brasília: 1998. p. 16-17.

WEISS, A. Survey of Egeria densa accessions for genetic similarity by Random Amplified Polymorphic DNA analysis (RAPDs). Aquatic Weed Control Investigations. Annual Report, 1997. p. 69-73.

WILLIAMS, J. G. K.; KUBELIK, A. R. K.; LIVAK, J. L. DNA polymorphisms amplified by arbitrary primers are useful as genetic markers. Nucleic Acids Res., v. 18, p. 6531-6535, 1990.

ZETTLER, F. W.; FREEMAN, T. E. Plant pathogens as biocontrols of aquatic weeds. Ann. Rev. Phytopathol., v. 10, p. 455-470, 1972. 